Article

\title{
Who Is Eligible for Telework? Exploring the Fast-Growing Acceptance of and Ability to Telework in Sweden, 2005-2006 to 2011-2014
}

\section{Erik Elldér}

Department of Economy and Society, University of Gothenburg, P.O. Box 625, SE-405 30 Gothenburg, Sweden; erik.ellder@geography.gu.se

Received: 11 June 2019; Accepted: 26 June 2019; Published: 27 June 2019

\begin{abstract}
The share of Swedish employees eligible for telework, that is, when work tasks and contractual agreement allow, increased from $22 \%$ in $2005-2006$ to $35 \%$ in 2011-2014. This article explores this fast diffusion of telework eligibility. Micro data from representative national surveys are used to examine how increasing opportunities for telework have spread among different groups of employees and different parts of the labour market and to examine the factors that increase or decrease the probability of being eligible for telework. We find significant increases in telework eligibility in almost all categories of workers and all labour market sectors. However, employees are clearly grouped into those achieving rapid gains in telework eligibility and those achieving such gains much more slowly. Telework continues to be primarily available to high-status segments of the labour market. Information and communication technology and technical solutions increasingly appear to be key factors enabling telework.
\end{abstract}

Keywords: telework; telecommuting; eligibility; Sweden; information and communication technology

\section{Introduction}

For several decades, many authors have maintained that telework has largely failed to meet the high expectations articulated in early forecasts and visions by not spreading to a larger population of workers and jobs (e.g., Hynes 2014; Pyöriä 2003). However, recent surveys in the United Kingdom (UK) (Felstead and Henseke 2017) and the United States of America (USA) (Tavares 2017) detect signs of the accelerating spread of telework and telework is becoming widespread in countries such as Denmark, the Netherlands and Luxembourg (Ojala and Pyöriä 2017). A particularly notable increase has recently been observed in Sweden, where the proportion of workers who reported regular teleworking increased from around 10\% in 2005 to over 20\% in 2012 and continues to grow (Vilhelmson and Thulin 2016). Behind this rapid growth lies, at least in Sweden, a combination of increasing employer willingness to permit telework, more work tasks being suitable for telework and advances in information and communication technology (ICT) (Vilhelmson and Thulin 2016). The share of Swedish employees eligible for telework, that is, when work tasks and contractual agreement allow, increased from $22 \%$ in 2005-2006 to 35\% in 2011-2014.

As technical solutions and issues of organization, management and control are believed to be at the forefront of current telework diffusion, important questions arise concerning how growing telework eligibility is distributed among different groups of employees and different labour market sectors. Some authors warn of an emerging telework divide if the gap widens between groups of employees traditionally eligible for telework and those not eligible (Callier 2012; Lee and Kim 2017; Mahler 2012). Opportunities to telework have typically been concentrated in high-status jobs and are typically regarded as a form of benefit with mostly positive effects on individual employees (Gajendran 
and Harrison 2007; Tavares 2017). Being occasionally allowed to work remotely from the regular workplace has often built loyalty and trust between employers and employees and has been considered more suitable in jobs involving high autonomy and freedom in which many tasks are performed individually and that are more result oriented and in little need of monitoring, control and supervision (Bailey and Kurland 2002).

At first sight, it is reasonable to believe that increasing telework eligibility is likely concentrated in jobs, employees and workplaces that have traditionally had higher shares of teleworkers, such as high-income earners, the highly skilled and advanced service employees. In sectors in which telework has not been that widespread, it may take a long time to abandon traditional management cultures of direct control and achieve a 'culture of telework' (Pyöriä 2011) and many low-skill jobs still require physical co-presence at the workplace. Pyöriä (2003) predicted several years ago that working free of spatial and temporal restraints would remain a privilege for only a small minority of the workforce. However, in retrospect, such restricted development cannot be taken for granted in light of other restructuring processes currently in motion on the labour market, often cited as linked to the development of flexible work in general, including digitalization (Degryse 2016), precarization (Standing 2011), automation (Brynjolfsson and McAfee 2014), job polarization (Goos et al. 2009) and increased surveillance (Fairweather 1999; Sewell and Taskin 2015). Particularly with regard to the fast development of ICT and the increasing digitalization of various sectors of society, work traditionally not considered appropriate for telework from a management perspective might now be deemed suitable. When new technology permits updated methods of control and surveillance, managers' previous scepticism might relax (Fairweather 1999) and new labour market groups may be considered eligible for telework (Dunn 2009).

This article explores one important restructuring aspect, specifically, the development of telework eligibility (i.e. when work tasks and contractual agreement allow telework) during the period of fast telework diffusion in Sweden, from 2005-2006 to 2011-2014. Our specific aim is to examine how telework eligibility developed on the Swedish labour market (i.e. across sectors and among different groups of employees) during this period and to investigate the factors that increase or decrease the probability of being eligible for telework. We contribute to the telework literature by exploring an unprecedented period of growth in telework, treating Sweden as a precursor when it comes to the spread of ICT and the number of jobs in advanced services, perhaps pointing the way to the future. Few studies have yet explored how telework eligibility is developing in light of the fast diffusion of telework recently observed in many countries and extensive studies of telework eligibility using nationally representative data are rare, with most previous studies being limited to actual participation in telework. This lack is notable considering that factors such as job suitability and managers' willingness to permit telework are frequently cited as major constraints on telework and considered most predictive of who will adopt it (Bailey and Kurland 2002). Telework could have many benefits for employees, employers, organizations and society. Improved knowledge of the factors influencing telework eligibility is key to understand the diffusion of telework and its impacts. For example, workers not eligible for telework report lower levels of perceived fairness, job satisfaction and intention to stay than their teleworking colleagues (Lee and Kim 2017). A concentration of the rapid increase of telework to already privileged groups of workers and labour market sectors risks reinforcing this telework divide (Mahler 2012). Furthermore, it is not necessarily the employees who are eligible to telework who are most motivated to adopt telework and all workers eligible for telework might not choose to telework for various reasons. Opportunities to manoeuvre and benefit from the increasing flexibilization of labour are unequally distributed amongst gender, class, skill and so forth lines (Wajcman 2015).

Since nationally representative data comparable over time on telework eligibility are rare and telework is a 'fuzzy' concept we choose to present the data and key delimitations in the next section, while in the third section we review the literature, discuss factors contributing to telework eligibility and operationalize the aim in a set of hypotheses. This is followed by the statistical analysis and, finally, the conclusions. 


\section{Data and Delimitations}

Micro data from the Swedish National Travel Surveys (NTS) are used for the analysis. NTS includes a randomized and representative cross-sectional selection of the Swedish population. It amasses data on the travel and communication habits of people living in Sweden and is conducted by the governmental agency Transport Analysis. Unlike many corresponding surveys in other countries, NTS is also designed to capture daily practices of teleworking, mobile work (e.g., during commuting), tele- and videoconferencing, access to ICT and so forth. It has been used in previous research on telework in Sweden (e.g., Elldér 2017; Vilhelmson and Thulin 2016). Respondents answer a number of questions about when in the day, how often per week and month, where and for how long they practice telework and other forms of mobile and virtual work, as well as about the digital accessibility of the workplace. Questions are also asked about whether the employer allows telework and whether the respondent's work tasks are suitable for telework, allowing us to examine telework eligibility. The respondent are not given any examples of suitable work tasks but is given a clear definition of telework (see below). Information on a range of background factors is also collected, including gender, income, education, family status and industry sector. We use NTS data covering two periods: 2005-2006 and 2011-2014. The survey was not conducted in 2007-2010. The response rate was 68\% in 2005-2006 and 43\% in 2011-2014. For the purpose of the analysis, we select only respondents who were gainfully employed at the time of the survey, leaving a total of 8425 respondents in 2005-2006 and 8149 in 2011-2014. The design of the surveys was largely identical in both periods.

Like all surveys, the NTS comes with certain limitations, not least in defining telework. An often-mentioned puzzle in the telework literature is the lack of a general definition of the term (Sullivan 2003; Wilks and Billsberry 2007). Various widely differing definitions have been used, structured around three key elements: technology, location and organization (Messenger and Gschwind 2016). As permitted by the NTS data, we regard telework as work sometimes performed at any place other than the usual workplace during contracted working hours. Accordingly, telework does not include (as stated in the survey): 'work on your way to or from work (e.g., reading a report on the bus),' 'bringing your work home after working hours,' 'going on an errand during your work' or 'temporarily working at home due to a sick child and so forth.' Workers with mobile workplaces are also not included. Telework is not regarded as a full-time practice (e.g., homeworking), nor is a minimum time threshold used. Instead, the respondents report whether or not they telework regularly. Furthermore, it is not necessary that ICT be used for work to be considered teleworking, although a large majority of respondents stated that they used ICT when teleworking. In this paper, we differentiate employees who are eligible for teleworking regularly from those who are not. ${ }^{1}$ Employees are defined as eligible for telework when their work tasks are reported to be suitable for telework and the contractual agreement with the employer permits telework on a regular basis.

The factors found important for telework in the literature are often related to three overall levels: the societal, organizational/occupational and individual levels (Aguilera et al. 2016; Ojala and Pyöriä 2017; Skorstad and Ramsdal 2016). It represents a limitation of this study that it concentrates on the organizational/occupational and individual levels. The individual level concerns telework demographics (i.e. the sociodemographic traits of teleworkers such as gender, household situation, education and income) as well as various family life, work-life balance and wellbeing issues (e.g., Holloway 2007). At the organizational/occupational level, issues such as job suitability, technical solutions, work performance and contractual agreements are in focus (e.g., Pyöriä 2011). Being

1 We initially also investigated what groups of employees eligible for telework actually choose to adopt telework on a regular basis. However, we found smaller effects and explanatory power for adoption than for eligibility and similar factors that play a role in telework eligibility also do so in telework adoption. Other factors that we could not include in the analysis probably play a key role here. For various reasons, telework does not suit everyone and working remotely sometimes has negative effects on, for example, career advancement, stress, family relations and social relations at work. These are, however, not questions that can be answered by analyzing the data used here. 
essentially an extended travel survey, an important limitation of the NTS is that general perceptions and attitudes concerning the respondents' working life as regards, for example, job satisfaction, performance and wellbeing are not surveyed. Factors related to the societal level include economic fluctuations and compositional changes, such as a growing knowledge economy, financial crises and changing demographic profiles of the workforce (e.g., Felstead and Henseke 2017). In this case, we had limited opportunities to take direct account of the societal level. However, there were no major changes in labour legislation relating to telework in Sweden during the studied period and the overall sectoral and demographic profile of the labour force did not change to a significant extent (see Table 1). Certainly, the world was hit by the financial crisis in 2007-2008 but Sweden did not suffer as much as other countries and had largely recovered by 2011-2014. Overall, the main concern of the present study is to investigate the groups of employees and the labour market sectors in which telework eligibility is particularly widespread. In the next section, we review the literature and present our theoretical expectations by operationalizing our aim in a set of hypotheses.

Table 1. Variable definitions and descriptive statistics.

\begin{tabular}{|c|c|c|c|c|c|}
\hline \multirow{2}{*}{ Variable } & \multirow{2}{*}{ Definition/Category } & \multicolumn{2}{|c|}{ 2005-2006 } & \multicolumn{2}{|c|}{ 2011-2014 } \\
\hline & & $n$ & $\%$ & $n$ & $\%$ \\
\hline \multirow{2}{*}{ Eligible for telework? } & No & 6436 & 77.4 & 5228 & 64.9 \\
\hline & Yes & 1884 & 22.6 & 2830 & 35.1 \\
\hline \multirow{8}{*}{ Employment sector ${ }^{\dagger}$} & Knowledge-intensive industry & 816 & 10.1 & 593 & 7.6 \\
\hline & Capital-intensive industry & 333 & 4.1 & 306 & 3.9 \\
\hline & Labour-intensive industry & 530 & 6.5 & 452 & 5.8 \\
\hline & $\begin{array}{l}\text { Knowledge-intensive services: } \\
\text { advanced services }\end{array}$ & 910 & 11.2 & 1085 & 13.9 \\
\hline & $\begin{array}{l}\text { Knowledge-intensive services: } \\
\text { education }\end{array}$ & 1092 & 13.5 & 1112 & 14.2 \\
\hline & Knowledge-intensive services: other & 2306 & 28.5 & 2331 & 28.6 \\
\hline & Capital-intensive services & 581 & 7.2 & 634 & 8.1 \\
\hline & Labour-intensive services & 1532 & 18.9 & 1299 & 16.6 \\
\hline \multirow{2}{*}{ Internet access } & No broadband at home & 3020 & 36.3 & 1755 & 22.4 \\
\hline & Broadband at home & 5294 & 63.7 & 6064 & 77.6 \\
\hline \multirow{2}{*}{$\begin{array}{l}\text { Can access work } \\
\text { email remotely? }\end{array}$} & No & 5630 & 68.7 & 3433 & 44.7 \\
\hline & Yes & 2560 & 31.3 & 4245 & 55.3 \\
\hline \multirow{2}{*}{$\begin{array}{l}\text { Can access work } \\
\text { computer remotely? }\end{array}$} & No & 6927 & 85.2 & 5177 & 69.9 \\
\hline & Yes & 1205 & 14.8 & 2229 & 30.1 \\
\hline \multirow{4}{*}{ Education } & $<$ Upper secondary school & 1096 & 13.1 & 807 & 10.0 \\
\hline & Upper secondary school & 3976 & 47.5 & 3558 & 43.9 \\
\hline & Higher education $\leq 2$ years & 514 & 6.1 & 1345 & 16.6 \\
\hline & Higher education $>2$ years & 2784 & 33.3 & 2399 & 29.6 \\
\hline \multirow{4}{*}{ Income } & Lowest quartile & 1975 & 25.4 & 1817 & 25.0 \\
\hline & Second quartile & 2096 & 27.0 & 1853 & 25.5 \\
\hline & Third quartile & 1813 & 23.3 & 1942 & 26.8 \\
\hline & Highest quartile & 1883 & 24.2 & 1646 & 22.7 \\
\hline
\end{tabular}


Table 1. Cont.

\begin{tabular}{|c|c|c|c|c|c|}
\hline \multirow{2}{*}{ Variable } & \multirow{2}{*}{ Definition/Category } & \multicolumn{2}{|c|}{ 2005-2006 } & \multicolumn{2}{|c|}{ 2011-2014 } \\
\hline & & $n$ & $\%$ & $n$ & $\%$ \\
\hline \multirow{3}{*}{$\begin{array}{l}\text { Employment } \\
\text { contract }\end{array}$} & Permanent, full-time employed & 6194 & 73.6 & 6158 & 75.7 \\
\hline & Permanent, part-time employed & 1190 & 14.1 & 1164 & 14.3 \\
\hline & Temporary & 1035 & 12.3 & 809 & 9.9 \\
\hline \multirow{2}{*}{ Gender } & Male & 4106 & 48.7 & 3918 & 48.1 \\
\hline & Female & 4319 & 51.3 & 4231 & 51.9 \\
\hline \multirow{4}{*}{ Life course } & Younger, $15-44$ years old, no children & 1700 & 20.4 & 1197 & 14.8 \\
\hline & Parent, children $0-6$ years old & 1424 & 17.1 & 1441 & 17.8 \\
\hline & Parent, children $7-18$ years old & 2470 & 29.6 & 2401 & 29.7 \\
\hline & Older, $\geq 45$ years old, no children & 2748 & 32.9 & 3034 & 37.6 \\
\hline
\end{tabular}

${ }^{\dagger}$ In capital-intensive sectors, the relative consumption of the fixed-capital share of value-added at factor cost is at least $25 \%$. In the knowledge-intensive sectors, employees with three or more years of higher education constitute more than $5 \%$ of the workforce (if not already identified as capital intensive); the remaining sectors are categorized as labour intensive. As the knowledge-intensive service sector constitutes $40 \%$ of the total workforce, this sector is split into three categories: advanced services, education and other knowledge-intensive services.

\section{Theoretical Expectations and Operationalization}

Drawing on insights from relevant theory and previous literature, we develop nine hypotheses about what employees were more likely to be eligible for telework over the studied period. Operationalizing job suitability, technical solutions, job status, skill and work-life balance issues, our hypotheses concern the following nine factors: employment sector, broadband connection at home, virtual access to workplace computer system, virtual access to workplace email, education level, income, employment contract, gender and life course. These factors are further described and justified and their impact on telework eligibility is analysed using the advanced and detailed framework presented in this section. Descriptive statistics and precise definitions can be found in Table 1.

\subsection{Labor Market Sector}

In many empirical studies, the typical teleworker profile is highly educated, earning a high income and employed in a high-status job (Bailey and Kurland 2002; Hjorthol 2006; Luukinen 1996; Vilhelmson and Thulin 2016; Welz and Wolf 2010). However, some authors suggest that this profile mainly mirrors various sorting mechanisms at the occupational level (Bailey and Kurland 2002; Haddon and Brynin 2005; Peters et al. 2004) and that factors at the organizational and occupational levels are the most significant determinants of what employees will adopt telework (Bailey and Kurland 2002; Mokhtarian 1998). Empirical studies demonstrate that there is considerably higher use of telework in knowledge-based industry sectors such as advanced services and education (Vilhelmson and Thulin 2016; Welz and Wolf 2010). This reflects one of the main obstacles to telework, that is, job suitability and many work tasks are simply not suitable for telework. Telework has traditionally suited tasks in which employees control the work pace and have little need of face-to-face interaction and others' input and therefore suits work that requires concentration and adaption to individual work rhythms (Bailey and Kurland 2002; Tavares 2017). These job traits disqualify many professions from telework, such as traditional manual industry jobs and other jobs that require physical constant co-presence. In other jobs, co-presence is required for some tasks while other components can be completed at any place other than the usual workplace. In the statistical analysis, we use employment sector as one proxy for job suitability. A higher share of teleworkers could be expected in non-manual jobs performed by educated professionals in knowledge-based labour market sectors. Our precise classification of employment sectors is based on Swedish Standard Industrial Classification codes (SNI codes) that categorize each workplace according to the activity carried out there (see the Appendix A for the 
precise codes) and that were originally developed by the Swedish Agency for Economic and Regional Growth (NUTEK 2000). They classify all workplaces as capital-, knowledge- or labour-intensive industry or service sectors (see Table 1). Based mainly on the premise that job suitability is a key factor determining telework eligibility and that labour market sector to some extent mirrors this, we develop the following hypothesis:

Hypothesis $\mathbf{1}$ (H1). Employees in knowledge-intensive industry, advanced services and the education sector are more likely to be eligible for telework over the studied period.

In opposition to our main expectations, the null hypothesis would be the possibility that telework eligibility is plateauing in knowledge-intensive industry, advanced services and the education sector. There is a long tradition of telework in these sectors (for the situation in Sweden, see Vilhelmson and Thulin 2001) and most suitable jobs might already have been made available for telework. Instead, due to expanding digitalization and associated transformations concerning monitoring and managers' acceptance, telework eligibility is perhaps now increasing mainly in other sectors and it is no longer more likely for workers in the expected sectors to be eligible for telework than in other sectors.

\subsection{Technical Solutions}

Often promoted as an important facilitator of telework, ICT has attracted much attention in the literature, fairly often being treated as the central factor contributing to the development of telework practices and adoption (Huws 1991; Nilles 1975; Messenger and Gschwind 2016). Work largely carried out using ICT (e.g., in front of a computer screen) is theoretically possible wherever the technology is available. Messenger and Gschwind (2016) referred to telework adoption and spread as an evolutionary process represented by 'three generations of telework' — home office, mobile office and virtual office-with the advance of ICT seen as the main contributor to the development. As ICT is becoming increasingly accessible, evolving from being stationary to being available anytime and anywhere, simultaneously becoming an increasing part of many jobs, telework options are also widening. In Sweden, for example, more than $90 \%$ of teleworkers use ICT when teleworking and the growth in telework goes hand in hand with rapidly increasing access to broadband and drastically improved technical solutions (e.g., possibilities to connect remotely to the workplace computer system; Vilhelmson and Thulin 2016). In the UK, the share of teleworkers not relying on ICT fell from a fifth in 1997 to one tenth in 2014 (Felstead and Henseke 2017). Accordingly, we anticipate that telework eligibility will become generally more widespread and increase faster among employees who rely on ICT and have access to appropriate technical solutions. We include three indicators capturing how work-related activities are enabled by ICT outside the regular workplace: access to broadband connection at home as well as the possibility to connect remotely to the workplace computer system (e.g., VPN) and to workplace e-mail. Our precise expectations are as follows:

Hypothesis $\mathbf{2} \mathbf{( H 2 )}$. Employees who can connect remotely to the workplace computer system are more likely to be eligible for telework over the studied period.

Hypothesis 3 (H3). Employees who can connect remotely to their work email are more likely to be eligible for telework over the studied period.

Hypothesis 4 (H4). Employees with access to a broadband connection at home are more likely to be eligible for telework over the studied period.

Technology is obviously changing the nature of telework, revolutionizing the way many work tasks are performed (Messenger and Gschwind 2016). However, some previous research does not confirm ICT as a requisite for telework. Yet the relative absence of telework in many highly developed countries suggests that the extensive spread of affordable and efficient ICT alone does not lead to high 
telework diffusion (Hjorthol 2006; Scott et al. 2012). In Japan, for example, telework has even decreased in recent years (Kimata and Takahasi 2017). According to some authors, ICT should therefore be seen as a facilitator rather than a precondition of telework (Haddon and Brynin 2005). In a recent study in France, only $2 \%$ of respondents cited the absence of appropriate technical tools as a hindrance to telework (Aguilera et al. 2016). In contrast to our main expectations, the null hypotheses in this case would be that it is not more likely for an employee who has virtual access to the workplace to be eligible for telework and that telework eligibility is not increasing faster among these workers.

\subsection{Skill and Status}

Global measures of job suitability based on, for example, industry sector and ICT practices need to be complemented with other factors. Brenke (2016), for example, claimed that $40 \%$ of jobs in Germany were suitable for telework since these jobs involve ICT but noted that the telework adoption rate in Germany was only 12\% (as cited by Eurofound 2017, p. 13). Other key factors such as individual perception of job suitability, status and power issues and organizational aspects are masked if only such objective and global job suitability factors are considered (Bailey and Kurland 2002; Mokhtarian 1998).

Although a particular job may be suitable for telework in theory, this does not mean that the employer will allow employees to work remotely. Teleworking has generally been found to be much more widespread in high-status jobs and among high-income earners and the highly educated (Bailey and Kurland 2002; Hjorthol 2006; Luukinen 1996; Vilhelmson and Thulin 2016; Welz and Wolf 2010). Employers are also more likely to offer work-at-home options to full-time than part-time employees (Global Workplace Analytics 2017). Besides the pattern of highly skilled and high-status employees being more likely to be employed in telework-suitable jobs (i.e. with the job traits discussed above), a central factor in this context is the organizational level (Hynes 2014; Pyöriä 2011). There is often scepticism about telework on the part of many employers (Aguilera et al. 2016) and it may be demanding to introduce telework because doing so requires changes in how work is organized and controlled (Brodt and Verburg 2007; Illegems et al. 2001). Management may lack trust (Lai and Burchell 2008), not least when it comes to technical as well as social possibilities to monitor, control and supervise employees when teleworking.

Social exchange theory can help explain why some workers are eligible for telework and others are not (Callier 2012; Felstead and Henseke 2017). This theory is based on the idea of mutual benefit among employees and employers (Cropanzano and Mitchell 2005): workers who are more committed, higher performing and display more positive attitudes toward the employer gain benefits, which might encourage them to work even harder and further strengthen the employer-employee bond. From the perspective of the individual employee, telework is often seen as a form of benefit, generally having positive outcomes including increased work engagement (Gerards et al. 2018), less time pressure and stress and higher perceived autonomy and job satisfaction as well as lower turnover intent, work-family conflict (Gajendran and Harrison 2007). Empirical evidence indicates that teleworkers are characterized by high levels of self-motivation, work knowledge and skill, independence, confidence and time management and organizational skills (Tavares 2017). These characteristics determine whether telework has a positive impact on individuals as they are relevant to the 'way people design strategies to deal with the obstacles of teleworking' (Tavares 2017, p. 32). Telework has also been found to be positively associated with the quality of the employee-supervisor relationship and with objective ratings of performance (Gajendran and Harrison 2007). As discussed above, our data do not capture any direct measures of employee-employer relations; instead, we use three variables capturing job status and skill: income, education level and employment contract. We expect highly educated workers with higher salaries and permanent employment contracts to have better opportunities to telework and that telework eligibility will increase faster among these workers than among other groups:

Hypothesis 5 (H5). Employees with higher education are more likely to be eligible for telework over the studied period. 
Hypothesis 6 (H6). High-income earners are more likely to be eligible for telework over the studied period.

Hypothesis 7 (H7). Permanently employed workers are more likely to be eligible for telework over the studied period.

These are our main expectations as regards the eligibility dimension. However, in light of the recent telework take-off, there may be grounds for revaluation if telework diffuses into precarious and low-status segments of the labour market (Dunn 2009). The general flexibilization of labour is not just concentrated in high-status jobs but is at least as evident among low-skilled and low-income employees (Standing 2011). In this context, it is important to note that the ability to benefit from this increasing flexibility varies among individuals and households (Wajcman 2015). High-status employees generally have more freedom to schedule their working hours, for example, to synchronize them with other household members' routines, while those in low-status jobs often have much less control over their work schedules (Lesnard 2008). Telework does not necessarily mean higher self-autonomy for all employees and could be deployed as a new means of employee control when managers, utilizing new technology, are able to closely supervise employees working remotely (Fairweather 1999; Sewell and Taskin 2015). This may in turn relax many employers' previous scepticism and new groups of low-skill and low-status workers may become eligible for telework, whether voluntary or involuntary.

\subsection{Work-Life Balance and Gender}

Finally, it is also important to relate any analysis of telework to different household and personal conditions, such as gender, age and household situation (Thulin et al. 2019). Telework has different meanings, rationales and consequences for different groups of workers. It is not only the employer who has a say when it comes to the right and opportunity to telework. In organizational research, there is a long tradition of studies of how employers respond to institutional pressures in general and to work-life balance issues in particular (Goodstein 1994; Oliver 1991). Such theories of organizational adoption have also been applied in telework research (Felstead and Henseke 2017). Some employees may exert strong pressure to gain the opportunity to telework. Many employers may be prompted to adapt their contractual agreements with, not least, parents of small children to offer working arrangements that better fit their employees' domestic sphere. Previous research demonstrates that many teleworkers enjoy a better balance between home life and work life (Tavares 2017) and experience less time pressure and stress (Vesala and Tuomivaara 2015). We believe that when the general barriers to telework (e.g., technical solutions, as discussed above) are relaxed, institutional pressures in general and organizational responsiveness to work and family issues in particular become increasingly important when it comes to telework eligibility. We therefore expect telework eligibility to be greater and to increase faster among the parents of young children than among workers in general:

Hypothesis 8 (H8). Parents of small children are more likely to be eligible for telework over the studied period.

Furthermore, although women have more often been found to mention family benefits and better work-life balance as incentives to adopt telework (Mokhtarian et al. 1998), we anticipate a higher likelihood that men will be eligible for telework. Many previous studies have found that telework is more widespread among men than women (Hjorthol 2006; Vilhelmson and Thulin 2016), partly explained by a gender-segmented labour market in which men are overrepresented in high-income jobs (cf. H6) and in sectors such as advanced services (cf. H1). Moreover, studies have found that teleworking men draw more distinct boundaries between their family life and work life, while these boundaries often are blurrier for women (Holloway 2007; Hultén 2005) and some studies have found working from home to have negative effects on women's status at work (Holloway 2007). The Swedish labour market is still clearly gender segmented in general and we would expect men to be more likely to be eligible for telework over the studied period:

Hypothesis 9 (H9). Men are more likely to be eligible for telework over the studied period. 
However, as gender equality in the Swedish labour market is improving somewhat over time (e.g., the wage gap is becoming somewhat smaller; Medlingsinstitutet 2016), telework eligibility could increase faster for women. In fact, some previous studies find women overrepresented among teleworkers (Bailey and Kurland 2002).

\section{Statistical Analysis}

Cross tabulation and binary logistic regressions are used to explore how telework eligibility develops within different groups of employees and to analyse the factors influencing telework eligibility. Table 2 presents the cross tabulation and shows the percentages of employees eligible for telework within the categorized respondent groups. Percentage points are used to indicate the changes in telework eligibility over time. The baseline observation is that the share of employees eligible for telework increased by 12.5 percentage points, from $22.6 \%$ in $2005-2006$ to $35.1 \%$ in $2011-2014$. Table 3 presents two logistic regressions of the likelihood of being eligible for telework in 2005-2006 and 2011-2014, respectively. The dependent variable 'telework eligibility' was coded ' 1 ' if the employee was eligible for telework and ' 0 ' if not. Only the best-fit models are presented and non-significant variables are omitted. Note that fitting this type of logistic regression does not allow us to compare whether changes between the two cross-sectional surveys are significant but it does allow us to test how the factors work in combination and to explore whether the effects of different variables increase, decrease or remain stable over the two periods. The explanatory power of the model can be illustrated by the proportion of correct classifications reported in Table 3, indicating that the predictions of employees' telework eligibility are correct in $76.0 \%$ of cases in $2005-2006$ and in $80.8 \%$ of cases in $2011-2014$. These high values attest to the key importance of the factors evaluated here.

As expected, employment sector appears to have an important sorting effect on telework eligibility. In traditional labour-intensive industry, only $11.3 \%$ of employees were eligible for telework in 2005-2006, compared with $27.8 \%$ of employees working in knowledge-intensive industry (e.g., electronics manufacturing), almost one-third in the education sector and $40.5 \%$ in advanced services (see Table 2). In labour-intensive (e.g., restaurant and retail) and capital-intensive (e.g., logistics and real estate) service sectors, $18.8 \%$ and $21.9 \%$, respectively, were eligible to telework in 2005-2006. In other knowledge-intensive services (e.g., healthcare and public administration), 17.7\% of employees were eligible for telework in 2005-2006. These differences clearly widened over time as the proportion of employees eligible for telework increased by 19.9 percentage points in advanced services, 16.5 percentage points in knowledge-intensive services and 14.5 percentage points in the education sector. These increases are significantly greater than in all other sectors besides capital-intensive industry, in which the proportion of employees eligible for telework increased by 14.9 percentage points. Notably, $60.4 \%$ of the employees in the advanced service sector were eligible for telework in 2011-2014. 
Table 2. Telework eligibility: personal and employment characteristics, within-group shares ( $95 \%$ confidence intervals in parentheses) and relative changes.

\begin{tabular}{|c|c|c|c|}
\hline & 2005-2006 & 2011-2014 & $\begin{array}{c}\text { Change } \\
\text { (Percentage Points) }\end{array}$ \\
\hline Total & $22.6 \%(21.7-23.5)$ & $35.1 \%(34.1-36.2)$ & +12.5 \\
\hline \multicolumn{4}{|l|}{ Employment sector } \\
\hline Knowledge-intensive industry & $27.8 \%(24.7-30.9)$ & $44.3 \%(40.3-48.3)$ & +16.5 \\
\hline Capital-intensive industry & $17.0 \%(12.9-21.1)$ & $31.9 \%(26.6-37.1)$ & +14.9 \\
\hline Labour-intensive industry & $11.3 \%(8.5-14.0)$ & $22.9 \%(19.0-26.8)$ & +11.6 \\
\hline Knowledge-intensive services: advanced services & $40.5 \%(37.3-43.7)$ & $60.4 \%(57.5-63.4)$ & +19.9 \\
\hline Knowledge-intensive services: education & $29.8 \%(27.1-32.5)$ & $44.3 \%(41.4-47.2)$ & +14.5 \\
\hline Knowledge-intensive services: other & $17.7 \%(16.1-19.2)$ & $27.9 \%(26.1-29.7)$ & +10.2 \\
\hline Capital-intensive services & $21.9 \%(18.5-25.3)$ & $30.5 \%(26.9-34.1)$ & +8.6 \\
\hline Labour-intensive services & $18.8 \%(16.8-20.7)$ & $26.4 \%(24.0-28.8)$ & +7.6 \\
\hline \multicolumn{4}{|l|}{ Internet } \\
\hline Broadband at home & $25.8 \%(24.6-26.9)$ & $38.1 \%(36.8-39.3)$ & +12.3 \\
\hline No broadband at home & $17.2 \%(15.9-18.6)$ & $28.5 \%(26.4-30.6)$ & +11.3 \\
\hline \multicolumn{4}{|l|}{ Can access work email remotely? } \\
\hline Yes & $45.9 \%(43.9-47.8)$ & $58.0 \%(56.5-59.5)$ & +12.1 \\
\hline No & $12.4 \%(11.5-13.3)$ & $10.0 \%(9.0-11.0)$ & -2.4 \\
\hline \multicolumn{4}{|l|}{ Can access work computer remotely? } \\
\hline Yes & $60.1 \%(57.3-62.9)$ & $78.1 \%(76.3-79.8)$ & +18.0 \\
\hline No & $16.4 \%(15.5-17.3)$ & $19.0 \%(17.9-20.1)$ & +2.6 \\
\hline \multicolumn{4}{|l|}{ Education } \\
\hline$<$ Upper secondary school & $7.4 \%(5.9-9.0)$ & $12.9 \%(10.5-15.2)$ & +5.5 \\
\hline Upper secondary school & $14.9 \%(13.8-16.0)$ & $21.7 \%(20.3-23.1)$ & +6.8 \\
\hline Higher education $\leq 2$ years & $34.5 \%(30.4-38.7)$ & $43.2 \%(40.5-45.8)$ & +8.7 \\
\hline Higher education $>2$ years & $37.7 \%(35.9-39.5)$ & $58.2 \%(56.2-60.2)$ & +20.5 \\
\hline \multicolumn{4}{|l|}{ Income } \\
\hline Lowest quartile & $7.7 \%(6.5-8.9)$ & $12.8 \%(11.3-14.3)$ & +5.1 \\
\hline Second quartile & $14.6 \%(13.1-16.1)$ & $24.9 \%(23.0-26.9)$ & +10.3 \\
\hline Third quartile & $25.8 \%(23.7-27.8)$ & $40.2 \%(38.1-42.4)$ & +14.4 \\
\hline Highest quartile & $47.9 \%(45.6-50.1)$ & $71.3 \%(69.1-73.5)$ & +23.4 \\
\hline \multicolumn{4}{|l|}{ Employment contract } \\
\hline Permanent, full-time employed & $25.7 \%(24.6-26.8)$ & $39.6 \%(38.4-40.9)$ & +13.9 \\
\hline Permanent, part-time employed & $13.2 \%(11.3-15.1)$ & $21.7 \%(19.3-24.1)$ & +8.5 \\
\hline Temporary & $15.5 \%(13.2-17.7)$ & $20.3 \%(17.5-23.1)$ & +4.8 \\
\hline \multicolumn{4}{|l|}{ Gender } \\
\hline Male & $25.0 \%(23.7-26.3)$ & $38.2 \%(36.7-39.7)$ & +13.2 \\
\hline Female & $20.4 \%(19.2-21.6)$ & $32.3 \%(30.9-33.7)$ & +11.9 \\
\hline \multicolumn{4}{|l|}{ Life course } \\
\hline Younger, $15-44$ years, no children & $22.9 \%(20.8-24.9)$ & $33.6 \%(30.9-36.3)$ & +10.7 \\
\hline Parent, children $0-6$ years old & $29.3 \%(26.9-31.7)$ & $46.2 \%(43.6-48.8)$ & +16.9 \\
\hline Parent, children $7-18$ years old & $21.4 \%(19.7-23.0)$ & $36.4 \%(34.5-38.3)$ & +15.0 \\
\hline Older, $\geq 45$ years, no children & $20.4 \%(18.9-21.9)$ & $29.8 \%(28.2-31.4)$ & +9.4 \\
\hline
\end{tabular}


Table 3. Logistic regressions of telework eligibility.

\begin{tabular}{|c|c|c|c|c|c|c|}
\hline & \multicolumn{3}{|c|}{ 2005-2006 } & \multicolumn{3}{|c|}{ 2011-2014 } \\
\hline & B & Sig. & OR & B & Sig. & OR \\
\hline \multicolumn{7}{|c|}{ Employment sector (ref = Knowledge-intensive services: other) } \\
\hline Knowledge-intensive industry & 0.379 ** & 0.001 & 1.460 & $0.439 * *$ & 0.002 & 1.551 \\
\hline Capital-intensive industry & -0.129 & 0.486 & 0.879 & -0.069 & 0.712 & 0.933 \\
\hline Labour-intensive industry & -0.057 & 0.741 & 0.944 & 0.222 & 0.206 & 1.249 \\
\hline $\begin{array}{l}\text { Knowledge-intensive services: advanced } \\
\text { services }\end{array}$ & $0.618^{* *}$ & 0.000 & 1.855 & $0.948^{* *}$ & 0.000 & 2.579 \\
\hline Knowledge-intensive services: education & 0.176 & 0.090 & 1.193 & $0.251 *$ & 0.016 & 1.285 \\
\hline Capital-intensive services & $0.341^{*}$ & 0.015 & 1.406 & $0.382 * *$ & 0.009 & 1.465 \\
\hline Labour-intensive services & $0.375^{* *}$ & 0.000 & 1.455 & 0.217 & 0.069 & 1.242 \\
\hline \multicolumn{7}{|c|}{ Can access work email remotely? $(r e f=$ Yes $)$} \\
\hline No & $-0.885^{* *}$ & 0.000 & 0.413 & $-1.238 * *$ & 0.000 & 0.290 \\
\hline \multicolumn{7}{|c|}{ Can access work computer remotely? $(r e f=Y e s)$} \\
\hline No & $-0.855^{* *}$ & 0.000 & 0.425 & $-1.516^{* *}$ & 0.000 & 0.219 \\
\hline \multicolumn{7}{|c|}{ Education (ref = Upper secondary school) } \\
\hline$<$ Upper secondary school & $-0.465^{* *}$ & 0.001 & 0.628 & -0.247 & 0.128 & 0.781 \\
\hline Higher education $\leq 2$ years & $0.529 * *$ & 0.000 & 1.697 & $0.517^{* *}$ & 0.000 & 1.677 \\
\hline Higher education $>2$ years & $0.606^{* *}$ & 0.000 & 1.832 & $0.791 * *$ & 0.000 & 2.207 \\
\hline \multicolumn{7}{|l|}{ Income (ref = Lowest quartile) } \\
\hline Second quartile & $0.566 * *$ & 0.000 & 1.760 & $0.561 * *$ & 0.000 & 1.752 \\
\hline Third quartile & $1.107 * *$ & 0.000 & 3.026 & $0.908^{* *}$ & 0.000 & 2.480 \\
\hline Highest quartile & $1.767 * *$ & 0.000 & 5.852 & $1.718^{* *}$ & 0.000 & 5.571 \\
\hline \multicolumn{7}{|c|}{ Gender $(r e f=$ Male $)$} \\
\hline Female & $0.256^{* *}$ & 0.000 & 1.291 & $0.237^{* *}$ & 0.003 & 1.268 \\
\hline \multicolumn{7}{|c|}{ Life course ( $r e f=$ Older,$\geq 45$ years, no children) } \\
\hline Younger, 15-44 years old, no children & $0.246^{*}$ & 0.010 & 1.280 & $0.253 *$ & 0.022 & 1.288 \\
\hline Parent, children $0-6$ years old & $0.332 * *$ & 0.000 & 1.393 & $0.328^{* *}$ & 0.001 & 1.388 \\
\hline Parent. children $7-18$ years old & 0.079 & 0.339 & 1.083 & 0.142 & 0.094 & 1.153 \\
\hline \multicolumn{7}{|c|}{ Model statistics } \\
\hline Constant & -1.697 & 0.000 & 0.184 & -0.816 & 0.000 & 0.442 \\
\hline$\%$ correct & & $76.0 \%$ & & & $80.8 \%$ & \\
\hline Cox \& Snell $r^{2}$ & & 0.219 & & & 0.382 & \\
\hline Nagelkarke $r^{2}$ & & 0.328 & & & 0.518 & \\
\hline
\end{tabular}

The regressions confirm that the influence of employment sector on the likelihood of being eligible for telework is also significant when controlling for other factors (Table 3). Being employed in knowledge-intensive industry, advanced services or labour-intensive services was consistently positively related to telework eligibility and employees in these sectors were more likely to have the opportunity to telework than those employed in other knowledge-intensive services (e.g., healthcare and public administration). In addition, being employed in the advanced service sector became increasingly important between 2005-2006 and 2011-2014, with employees in this sector being 2.6 times more likely to be eligible for telework in 2011-2014 versus 1.9 times more likely in 2005-2006. While being employed in labour-intensive services was significantly related to telework eligibility in 2005-2006, it was not significantly related in 2011-2014. Working in the educational sector did not make a significant difference compared with being employed in other knowledge-intensive services in 2005-2006 but had 
a positive and significant effect in 2011-2014. These results largely support H1, which postulates that telework eligibility is generally more widespread in knowledge-intensive industry, advanced services and the education sector than other sectors in both periods.

When it comes to technical solutions, there are large differences between those who can access work email or computer systems outside the workplace and those who cannot: $78.1 \%$ of those who could connect to the work computer system from home also had the opportunity to work remotely in 2011-2014 (Table 2). At the same time, only 10.0\% of those who could not access work email outside the workplace (including those who did not have work email) were eligible for telework. These gaps clearly widened over time and 18.0 percentage points more employees who could access the work computer system remotely were eligible for telework compared with only 2.6 percentage points more of those who could not. Those who could not access work email outside the workplace were the only group in which the proportion of telework-eligible workers declined over time. The virtual accessibility of the workplace is still of key importance when we control for other factors (see Table 3). Those who could not connect to work email or the work computer system from home were significantly less likely to be eligible for telework. The strength of the relationship between technological factors and telework eligibility increased between 2005-2006 and 2011-2014. If employees did not have remote access to the workplace computer system, their odds of being eligible for telework, compared with employees who had access, was 2.4 times less in 2005-2006 and 4.6 times less in 2011-2014. These results clearly support the predictions made in $\mathrm{H} 2$ and $\mathrm{H} 3$. Access to broadband in the home, however, was not significant after controlling for the more specific technological factors, so $\mathrm{H} 4$ is rejected.

The differences between low-skilled and highly educated employees and between low-income and high-income earners were expected and the magnitude of the gaps is noteworthy. In 2011-2014, only $12.9 \%$ of employees with the lowest level of education had the opportunity to telework, compared with $58.2 \%$ of those with more than two years of higher education (see Table 2). Similarly, $12.8 \%$ of the lowest income quartile was eligible for telework in 2011-2014, compared with 71.3\% in the highest income quartile. This high/low-status gap widened over time. The proportion of highly educated employees eligible for telework increased by 20.5 percentage points but among those who lacked higher education there was only a 5-7 percentage point increase. The share of telework-eligible employees in the highest income quartile increased by 23.4 percentage points, compared with only 5.1 percentage points in the lowest income quartile. The regression analysis presented in Table 3 confirms that both education and income levels also had strong positive effects when controlling for other factors. Higher education or income greatly increased the likelihood of being eligible for telework in both periods. Employees in the highest income quartile were almost six times more likely to have the contractual right to telework and to have suitable job tasks than did employees of the lowest income quartile in both periods. These results clearly support our expectations (H5 and H6). However, employment contract had no significant effect after controlling for the other variables, rejecting H7.

Among the different life course categories, 'Parent, children 0-6 years old' stands out: significantly more within this group were eligible for telework than were employees in other stages of life. The share of parents of children aged 0-6 years eligible for telework also increased faster than did the share in the other life course groups. The regression analysis also supports what we expected (H8), that is, that parents with children seven years old or younger were significantly more likely to be eligible for telework than were employees older than 45 years in both periods.

A larger proportion of men had the opportunity to telework in both periods. This gap widened over time: men and women differed by 4.6 percentage points in 2005-2006 versus 5.9 percentage points in 2011-2014 (Table 2). However, contrary to the bivariate analysis results and to our expectations (H9), women were more likely to be eligible for telework when controlling for other factors (Table 3). Closer analysis revealed that the main confounding factor is income and if income is not included in the model the effect of gender changes direction. Women are overrepresented in the lower income quartiles, in which significantly fewer employees are eligible for telework. 


\section{Concluding Discussion}

The ongoing spread of telework raises many important questions, not least relating to emerging labour market gaps and inequalities (Lee and Kim 2017; Mahler 2012). Telework has generally been seen as a privilege with many advantages, including higher job satisfaction, performance and perceived autonomy as well as less work-family conflict, mostly available to high-status employees (Gajendran and Harrison 2007). However, as telework becomes more widespread, new groups of employees and employers could become eligible for telework and there may be grounds for re-evaluating the factors traditionally found to be important for telework eligibility. It is also likely that fast diffusion will bring new meanings, practices and consequences for those who telework (Thulin et al. 2019). An important research task in this context and the aim of this paper, is to explore how the increase in telework eligibility is dispersed among different groups of employees and different parts of the labour market and to examine what factors increase or decrease the probability of being eligible for telework.

We found that a significant increase in telework eligibility can be observed in all labour market sectors and in almost all categories of workers. This is an important and interesting observation in itself, attesting to the major changes in the Swedish labour market when it comes to the acceptance of and opportunities for teleworking. However, this general upward trend does not necessarily guarantee convergence among different groups of employees. Employees are clearly grouped into those who achieve rapid gains in telework eligibility and those who achieve gains much more slowly. Workers who achieve rapid gains in telework eligibility have the sociodemographic and labour market profile that has traditionally yielded good opportunities for telework, for example, higher education, high income and employment in the advanced service sector. The gains are much slower among low-income employees lacking higher education, employed in labour-intensive industry and having limited opportunities to use ICT when working remotely from the regular workplace. We find firm evidence that telework continues to be strongly linked to high-status segments of the labour market: an employee in the highest income quartile is nearly six times more likely to be eligible for telework than is an employee in the lowest quartile and employees having more than two years of higher education are twice as likely to have the opportunity to telework than are employees lacking higher education. Technical solutions also appear to be a key factor enabling telework. Employees who could access the work computer system remotely were 2.4 times more likely to be eligible for telework in 2005-2006 and 4.6 times more likely in 2011-2016 than were employees without this ability. This could suggest that the development of ICT has contributed both to the increase in telework eligibility and to the diverging trends in telework eligibility. It is however important to acknowledge that we cannot draw far-reaching conclusions about causality, considering the cross-sectional data used here. However, this result draws attention to the fact that technological progress will not necessarily narrow the telework eligibility gap. Rather, jobs that are manual or require physical presence or both (for example traditional manual industry jobs, store clerks and assistant nurses) are probably destined to be left behind. Although it should be remembered that the development of ICT probably will have major impacts on these jobs in other ways (e.g., through artificial intelligence technology and automatization).

Furthermore, it is also important to keep in mind that our results say little about how telework eligibility will be distributed between different labour market segments in the future or about the future role of telework in the work environment. New technology brings new opportunities for management to maintain a traditional management culture of direct control by remotely controlling how and how long employees work, in contrast to the performance-based schemes to which many teleworkers have traditionally been subject. Low-skill jobs that involve less autonomy could then be made available for telework arrangements and new groups of employees previously not given the trust and opportunity may become eligible for telework. This would also probably transform the implications of telework and challenge its positive connotations, including the autonomy and sense of freedom currently often associated with telework. However, as discussed above, we find few indications that such a development has yet reached Swedish workplaces, at least on a large scale. It remains to be seen whether new management practices and technical solutions that give employers 
even more control will change this in the future. These are not, however, questions that can be answered through analysing the extensive data used here. The aim of this paper has been more modest, namely, to explore how telework eligibility has developed during a period of fast telework diffusion. In doing so, we have demonstrated that the telework eligibility gap in Sweden continues to expand, which in turn emphasizes the need for further research exploring the processes involved in telework eligibility and adoption in the contemporary, increasingly digitalized and flexible labour market.

Funding: This research was funded by Forte: Swedish Research Council for Health, Working Life and Welfare grant number 2016-01264.

Acknowledgments: The author would like to acknowledge the valuable comments of the anonymous reviewers.

Conflicts of Interest: The author declares no conflict of interest.

\section{Appendix A Definition of Employment Sector}

\begin{tabular}{|c|c|c|c|}
\hline Employment Sector & Description & SNI2002 (2005-2006) & SNI2007 (2011-2014) \\
\hline $\begin{array}{l}\text { Knowledge-intensive } \\
\text { industry }\end{array}$ & $\begin{array}{l}\text { Manufacturing of chemicals, } \\
\text { machinery, electronics, transport } \\
\text { equipment }\end{array}$ & $\begin{array}{c}22,24,29,30,31,32,33 \\
34,35\end{array}$ & $\begin{array}{c}18,20,21,26,27,28,29 \\
30,33\end{array}$ \\
\hline $\begin{array}{l}\text { Capital-intensive } \\
\text { industry }\end{array}$ & $\begin{array}{l}\text { Agriculture, forestry, mining, } \\
\text { electricity, gas and water supply, } \\
\text { manufacturing of pulp, paper, } \\
\text { coke, petroleum, basic metals }\end{array}$ & $\begin{array}{c}1,2,5,10,11,12,13,14 \\
21,23,27,40,41\end{array}$ & $\begin{array}{c}1,2,3,5,6,7,8,9,17,19, \\
24,35,36\end{array}$ \\
\hline $\begin{array}{l}\text { Labour-intensive } \\
\text { industry }\end{array}$ & $\begin{array}{l}\text { Manufacturing of food products, } \\
\text { textile and leather products, } \\
\text { plastic products, furniture }\end{array}$ & $\begin{array}{c}15,16,17,18,19,20,25 \\
26,28,36,37\end{array}$ & $\begin{array}{c}10,11,12,13,14,15,16 \\
22,23,25,31,32\end{array}$ \\
\hline $\begin{array}{l}\text { Knowledge-intensive } \\
\text { services: advanced } \\
\text { services }\end{array}$ & $\begin{array}{c}\text { Financial intermediation, } \\
\text { computer activities, research and } \\
\text { development, business activities }\end{array}$ & $65,66,67,72,73,74,99$ & $\begin{array}{c}58,60,62,63,64,65,66 \\
69,70,71,72,73,74,78 \\
80,81,82,99\end{array}$ \\
\hline $\begin{array}{l}\text { Knowledge-intensive } \\
\text { services: education }\end{array}$ & Education & 80 & 85 \\
\hline $\begin{array}{l}\text { Knowledge-intensive } \\
\text { services: other }\end{array}$ & $\begin{array}{l}\text { Public administration, health } \\
\text { and social work, recreational, } \\
\text { cultural and sporting activities }\end{array}$ & $75,85,91,92$ & $\begin{array}{c}59,75,84,86,87,88,90 \\
91,92,93,94\end{array}$ \\
\hline $\begin{array}{l}\text { Capital-intensive } \\
\text { services }\end{array}$ & $\begin{array}{l}\text { Transportation, post and } \\
\text { telecommunications, real estate }\end{array}$ & $60,61,62,63,64,70,71$ & $\begin{array}{c}41,49,50,51,52,53,61 \\
68,77,79\end{array}$ \\
\hline $\begin{array}{l}\text { Labour-intensive } \\
\text { services }\end{array}$ & $\begin{array}{l}\text { Construction, wholesale and } \\
\text { retail trade, hotels, restaurants, } \\
\text { sanitation }\end{array}$ & $\begin{array}{c}45,50,51,52,55,90,93 \\
95\end{array}$ & $\begin{array}{l}37,38,39,42,43,45,46 \\
47,55,56,95,96,97,98\end{array}$ \\
\hline
\end{tabular}

\section{References}

Aguilera, Anne, Virginie Lethiais, Alain Rallet, and Laurent Proulhac. 2016. Home-based Telework in France: Characteristics, Barriers and Perspectives. Transportation Research Part A 92: 1-11. [CrossRef]

Bailey, Diane, and Nancy Kurland. 2002. A Review of Telework Research: Findings, New Directions and Lessons for the Study of Modern Work. Journal of Organizational Behavior 23: 383-400. [CrossRef]

Brenke, Karl. 2016. Home Office: Möglichkeiten werden beiweitem nicht ausgeschöpft [Home Office: The Possibilities Are Far from Exhausted]. DIW Weekly Report No. 5/2016. Berlin: DIW.

Brodt, Torsten L., and Robert M. Verburg. 2007. Managing Mobile Work: Insights from European Practice. New Technology, Work and Employment 22: 52-65. [CrossRef]

Brynjolfsson, Erik, and Andrew McAfee. 2014. The Second Machine Age: Work, Progress and Prosperity in a Time of Brilliant Technologies. New York: W. W. Norton \& Company. 
Callier, James G. 2012. The Impact of Teleworking on Work Motivation in a U.S. Federal Government Agency. The American Review of Public Administration 42: 461-80. [CrossRef]

Cropanzano, Russel, and Marie S. Mitchell. 2005. Social Exchange Theory: An Interdisciplinary Review. Journal of Management 31: 874-900. [CrossRef]

Degryse, Christophe. 2016. Digitalisation of the Economy and its Impact on Labour Markets. Working Paper 2016.0, European Trade Union Institute. Brussels: ETUI aisbl.

Dunn, Hopeton S. 2009. Teleworking the Mobile Caribbean: Enabling Remote Work among the Marginalized in Jamaica and Trinidad and Tobago. Information Technology and International Development 5: 52-66.

Elldér, Erik. 2017. Does Telework Weaken Urban Structure-Travel Relationships? Journal of Transport and Land Use 10: 187-210. [CrossRef]

Eurofound. 2017. Working Anytime, Anywhere: The Effects on the World of Work. Luxembourg: Publications Office of the European Union.

Fairweather, N. Ben. 1999. Surveillance in Employment: The Case of Teleworking. Journal of Business Ethics 22: 39-49. [CrossRef]

Felstead, Alan, and Golo Henseke. 2017. Assessing the Growth of Remote Working and its Consequences for Effort, Well-being and Work-Life Balance. New Technology, Work and Employment 32: 195-212. [CrossRef]

Gajendran, Ravi. J., and David A. Harrison. 2007. The Good, the Bad and the Unknown about Telecommuting: Meta-Analysis of Psychological Mediators and Individual Consequences. Journal of Applied Psychology 92 1524-41. [CrossRef] [PubMed]

Gerards, Ruud, Andries de Grip, and Claudia Baudewijns. 2018. Do new ways of working increase work engagement? Personnel Review 47: 517-34. [CrossRef]

Global Workplace Analytics. 2017. 2017 State of Telecommuting in the U.S. Employee Workforce. Available online: https://www.flexjobs.com/2017-State-of-Telecommuting-US (accessed on 27 June 2019).

Goodstein, Jerry D. 1994. Institutional Pressures and Strategic Responsiveness: Employer Involvement in Work-Family Issues. Academy of Management Journal 37: 350-82.

Goos, Marten, Alan Manning, and Anna Salomons. 2009. Job Polarization in Europe. American Economic Review 99: 58-63. [CrossRef]

Haddon, Leslie, and Malcom Brynin. 2005. The Character of Telework and the Characteristics of Teleworkers. New Technology, Work and Employment 20: 34-46. [CrossRef]

Hjorthol, Randi J. 2006. Teleworking in Some Norwegian Urban Areas: Motives and Transport Effects. Urban Geography 27: 610-27. [CrossRef]

Holloway, Donell. 2007. Gender, Telework and the Reconfiguration of the Australian Family Home. Continuum Journal of Media \& Cultural Studies 21: 33-44.

Hultén, Kerstin. 2005. Leva och arbete i hemmet: Effekter av distansarbete i hemmet för privatliv och arbetsliv [Live and work at home: Effects of teleworking in the home for private life and working life]. Arbetsmarknad $\mathcal{E}$ Arbetsliv 11: 123-36.

Huws, Ursula. 1991. Telework: Projections. Futures 23: 19-30. [CrossRef]

Hynes, Michael. 2014. Telework Isn't Working: A Policy Review. The Economic and Social Review 45: 579-602.

Illegems, Viviane, Alain Verbeke, and Rosette S'Jegers. 2001. The Organizational Context of Teleworking Implementation. Technological Forecasting and Social Change 68: 275-91. [CrossRef]

Kimata, Akira, and Masayasu Takahasi. 2017. Transformation of the Nature of Managerial Work in Modernity: Evidence from the Japanese Workplace. Colombo Business Journal 8: 23-42. [CrossRef]

Lai, Yi, and Brendan Burchell. 2008. Distributed Work: Communicating in an "Officeless Firm". New Technology, Work and Employment 23: 61-76. [CrossRef]

Lee, David, and Sun Young Kim. 2017. A Quasi-Experimental Examination of Telework Eligibility and Participation in the U.S. Federal Government. Review of Public Personnel Administration 38: 451-71. [CrossRef]

Lesnard, Laurent. 2008. Off-Scheduling within Dual-earner Couples: An Unequal and Negative Externality for Family Time. American Journal of Science 114: 447-90. [CrossRef]

Luukinen, Ari. 1996. A Profile of Finnish Telework: Survey Results Concerning the Nature, Extent and Potential of Telework in Finland. In Directions of Telework in Finland: Report by the Finnish Experience with Telework Project; Edited by A. Luukinen. Helsinki: Ministry of Labour-Publication of Labour Administration, pp. 1-49.

Mahler, Julianne. 2012. The Telework Divide: Managerial and Personnel Challenges of Telework. Review of Public Personnel Administration 32: 407-18. [CrossRef] 
Medlingsinstitutet. 2016. Löneskillnaden mellan kvinnor och män 2015: Vad säger den officiella lönestatistiken? [Wage Differences between Men and Women 2015: What Can We Learn from Public Statistics on Wages and Salaries?]. Stockholm: Medlingsinstitutet.

Messenger, Jon C., and Lutz Gschwind. 2016. Three Generations of Telework: New ICT and the (R)evolution from Home Office to Virtual Office. New Technology, Work and Employment 31: 195-208. [CrossRef]

Mokhtarian, Patricia L. 1998. A Synthetic Approach to Estimating the Impacts of Telecommuting on Travel. Urban Studies 35: 215-41. [CrossRef]

Mokhtarian, Patricia L., Michael N. Bagley, and Ilan Salomon. 1998. The Impact of Gender, Occupation and Presence of Children on Telecommuting Motivations and Constraints. Journal of the American Society for Information Science 49: 1115-34. [CrossRef]

Nilles, Jack M. 1975. Telecommunications and Organizational Decentralization. IEEE Transactions on Communications 23: 1142-47. [CrossRef]

NUTEK. 2000. Arbetskraftens rörlighet: Ett smörjmedel för tillväxt [Labour Mobility: A Help for Economic Growth]. Stockholm: NUTEK.

Ojala, Satu, and Pasi Pyöriä. 2017. Mobile Knowledge Workers and Traditional Mobile Workers: Assessing the Prevalence of Multi-locational Work in Europe. Acta Sociologica 61: 402-18. [CrossRef]

Oliver, Christine. 1991. Strategic Responses to Institutional Processes. Academy of Management Review 16: 145-79. [CrossRef]

Peters, Pascale, Kea G. Tijdens, and Cécile Wetzels. 2004. Employees' Opportunities, Preferences and Practices in Telecommuting Adoption. Information E Management 41: 469-82.

Pyöriä, Pasi. 2003. Knowledge Work in Distributed Environments: Issues and Illusions. New Technology, Work and Employment 18: 166-80. [CrossRef]

Pyöriä, Pasi. 2011. Managing Telework: Risks, Fears and Rules. Management Research Review 34: 386-99. [CrossRef]

Scott, Darren M., Ivy Dam, Antonio Páez, and Robert D. Wilton. 2012. Investigating the Effects of Social Influence on the Choice to Telework. Environment and Planning A 44: 1016-31. [CrossRef]

Sewell, Graham, and Laurent Taskin. 2015. Out of Sight, Out of Mind in a New World of Work: Autonomy, Control and Spatiotemporal Scaling in Telework. Organization Studies 36: 1507-29. [CrossRef]

Skorstad, Egil J., and Helge Ramsdal. 2016. Flexible Organizations and the New Working Life: A European Perspective. Abingdon: Routledge.

Standing, Guy. 2011. The Precariat. London: Bloomsbury Academic.

Sullivan, Cath. 2003. What's in a Name? Definitions and Conceptualisations of Teleworking and Homeworking. New Technology, Work and Employment 18: 158-65. [CrossRef]

Tavares, Aida I. 2017. Telework and Health Effects Review. International Journal of Healthcare 3: 30-36. [CrossRef]

Thulin, Eva, Bertil Vilhelmson, and Martina Johansson. 2019. New Telework, Time Pressure and Time Use Control in Everyday Life. Sustainability 11: 3067. [CrossRef]

Vesala, Hanne, and Seppo Tuomivaara. 2015. Slowing work down by teleworking periodically in rural settings? Personnel Review 44: 511-28. [CrossRef]

Vilhelmson, Bertil, and Eva Thulin. 2001. Is Regular Work at Fixed Places Fading Away? The Development of ICT-based and Travel-based modes of Work in Sweden. Environment and Planning A 33: 1015-29. [CrossRef]

Vilhelmson, Bertil, and Eva Thulin. 2016. Who and Where the Flexible Workers? Exploring the Current Diffusion of Telework in Sweden. New Technology, Work and Employment 31: 77-96. [CrossRef]

Wajcman, Judy. 2015. Pressed for Time: The Acceleration of life in Digital Capitalism. Chicago: University of Chicago Press.

Welz, Christian, and Felix Wolf. 2010. Telework in the European Union. Dublin: European Foundation for the Improvement of Living and Working Conditions.

Wilks, Linda, and Jon Billsberry. 2007. Should We Do Away With Teleworking? An Examination of Whether Teleworking Can be Defined in the New World of Work. New Technology, Work and Employment 22: 168-77. [CrossRef]

(C) 2019 by the author. Licensee MDPI, Basel, Switzerland. This article is an open access article distributed under the terms and conditions of the Creative Commons Attribution (CC BY) license (http://creativecommons.org/licenses/by/4.0/). 